\title{
Problemy postępowania z zakresu przyznawania świadczeń emerytalnych. Studium przypadku i propozycja zmian
}

\section{Wstęp}

Duże kontrowersje budzi procedura przyznawania emerytur z Zakładu Ubezpieczeń Społecznych. Składa się ona zarówno z postępowania administracyjnego w ZUS, jak również postępowania cywilnego w przypadku ewentualnej niezgody na decyzję ZUS. Niepokój budzi również czas (przewlekłość) uzyskania ostatecznego rozstrzygnięcia w kwestii emerytury. Często jednak największym problemem jest wysokość uzyskiwanego świadczenia, które bywa niewystarczające na sfinansowanie normalnych warunków życia. Uwadze badacza wcale też nie umykają takie problemy jak trudności w odpowiedniej ocenie dowodów w sprawie, normy kolizyjne, niewłaściwe prowadzenie postępowania administracyjnego i sądowego, niejasne obliczenia emerytury, czy ogólny nieporządek.

Mnogość tych problemów prowadzi do konstatacji, że procedurę uzyskiwania świadczeń emerytalnych z ZUS należałoby zmienić. Wydaję się, że ewentualne zmiany w sposobie udzielania emerytur z Zakładu Ubezpieczeń Społecznych usprawniłyby procedurę przyznawania świadczeń i rozwiązałyby problemy. Powstaje pytanie, jakie zmiany należałoby rekomendować, aby owe problemy zlikwidować ${ }^{2}$.

\section{Cel i struktura}

Niniejsze opracowanie zostało oparte studium przypadku jednej z typowych spraw w zakresie uzyskiwania świadczenia emerytalnego. Na podstawie tych informacji zauważamy problemy występujące zarówno na gruncie procedury uzyskiwania świadczenia, jak też kwestionowania jego wysokości. Nadto odnotowujemy materialne problemy wpływające na podstawy i skutki uzyskania emerytury. W związku z tym, że niniejszy wywód został oparty na studium przypadku będzie się on składał z opisu sytuacji faktycznej i przedstawieniu wykrytych problemów. Istotną kwestią będzie odpowiednie naświetlenie za-

\footnotetext{
${ }^{1}$ Doktorant, Uniwersytet Pedagogiczny im. KEN w Krakowie, Wydział Humanistyczny, Instytut Politologii.

${ }^{2}$ Por. A. Wiktorow, Zabezpieczenie emerytalne w Polsce po transformacji ustrojowej. Możliwe kierunki dalszych zmian, „Przegląd Prawa i Administracji” 2014, nr 99, s. 11-27.
} 
chodzących problemów i przedstawienie strategii ich rozwiązania. Zrozumienie istnienia tych zjawisk oraz wdrożenie reform powinno skutkować znaczącym uzdrowieniem polskiego sytemu uzyskiwania świadczeń emerytalnych.

\section{Terminy i główne źródła}

Praca zostaje poświęcona wyłącznie świadczeniom emerytalnym przyznawanych przez Zakład Ubezpieczeń Społecznych (ZUS): emeryturze z Funduszu Ubezpieczeń Społecznych (FUS) wraz z kapitałem początkowym oraz okresowej emeryturze kapitałowej. Opracowanie nie dotyczy innych emerytur i rent. Wszelkie występujące pojęcia zostają zdefiniowane na gruncie dwóch ustaw: ustawy o emeryturach i rentach z Funduszu Ubezpieczeń Społecznych ${ }^{3}$ oraz ustawy o emeryturach kapitałowych ${ }^{4}$. Te dwa akty prawne obok szczegółowych zapisów Kodeksu postępowania cywilnego ${ }^{5}$ oraz Kodeksu postępowania administracyjnego ${ }^{6}$ będą stanowić podstawę dla dalszych rozważań. Wszystkie dane osobowe i informacje mogące prowadzić do identyfikacji stron postępowań zostały zanonimizowane.

\section{Opis przypadku}

Pierwszą część studium przypadku oparto na postępowaniu o ustalenie kapitału początkowego, wysokość emerytury z FUS oraz wysokość emerytury kapitałowej prowadzonego przez Zakład Ubezpieczeń Społecznych, oddział w A., wszczętego w dniu 10 stycznia 2014 roku na wniosek przyszłego emeryta, tutaj występującego jako J.F. (kobieta lat 63). Drugą część oparto o przebieg i akta sprawy odwoławczej od decyzji ZUS prowadzonej przez Sąd Okręgowy, IV Wydział Pracy i Ubezpieczeń Społecznych w A. i zakończonej nieprawomocnym wyrokiem w dniu 15 stycznia 2016 roku. Ostatnia część wywodu opiera się na aktach sprawy apelacyjnej, prowadzonej przez Sąd Apelacyjny, III Wydział Pracy i Ubezpieczeń Społecznych w K.

\footnotetext{
${ }^{3}$ Ustawa z dnia 17 grudnia 1998 r. o emeryturach i rentach z Funduszu Ubezpieczeń Społecznych, Dz.U. z 2016 r., poz. 887 ze zm., dalej: u.e.r.

${ }^{4}$ Ustawa z dnia 21 listopada 2008 r. o emeryturach kapitałowych, Dz.U. z 2014 r., poz. 1097, dalej: em. kap.

${ }^{5}$ Ustawa z dnia 17 listopada 1964 r. Kodeks Postępowania Cywilnego, Dz.U. z 2016 r., poz. 1822 ze zm., dalej k.p.c.

${ }^{6}$ Ustawa z dnia 14 czerwca 1960 r. Kodeks postępowania administracyjnego, Dz.U. z 2016 r., poz. 23 ze zm., dalej k.p.a.
} 


\subsection{Postępowanie administracyjne}

W dniu 10 stycznia 2014 roku J.F. złożyła do oddziału ZUS w A. wniosek o ustalenie kapitału początkowego, przyznanie emerytury z FUS oraz okresowej emerytury kapitałowej. Wniosek został złożony w zgodzie z art. 116, ust. 1 u.e.r. do oddziału ZUS właściwego ze względu na miejsce zamieszkania (art. 115, ust. 1, u.e.r.). W związku z art. 13 em.kap i art. 116a u.e.r. wszczęto także postępowanie o ustalenie okresowej emerytury kapitałowej oraz o ustalenie kapitału początkowego dla osób urodzonych po 31 grudnia 1948 roku (art. 173-185a w związku z art. 53 u.e.r. $)^{7}$. Wnioskodawczyni osiągnęła również stosowny wiek emerytalny dla wnioskowania o udzielenie jej świadczeń tj. 60 lat 7 miesięcy (art. 24, ust. 1a, pkt. 8 u.e.r.). Do wniosków określonych wzorem ZUS Wnioskodawczyni załączyła liczne dowody pozostawania w zatrudnieniu i odprowadzania składek na ubezpieczenia społeczne $\mathrm{m}$. in. umowy o pracę, świadectwa pracy, tzw. paski wynagrodzeń (art. 117 u.e.r.).

$\mathrm{Na}$ podstawie art. 124 u.e.r. w związku z art. 180 k.p.a. postępowanie w sprawie o przyznanie świadczeń toczy się pod rządami prawa administracyjnego. Jest to jednak postępowanie szczególne uregulowane na podstawie ustawy u.e.r. i innych ustaw. Niestety postępowanie o przyznanie świadczeń trwało bardzo długo. ZUS wielokrotnie wzywał Wnioskodawczynię do przedstawiania kolejnych dowodów opłacania składek na ubezpieczenie społeczne i pozostawania $\mathrm{w}$ zatrudnieniu. W związku z normą zawartą $\mathrm{w}$ art. 118 ust. 1 u.e.r. organ rentowy wydaje decyzję w sprawie świadczeń emerytalnych w terminie 30 dni od momentu wyjaśnienia ostatniej okoliczności niezbędnej do wydania tej decyzji. W związku z wielokrotnymi wezwaniami organu do uzupełniania materiału dowodowego, decyzję ustalającą prawo i wysokości kapitału początkowego J.F. wydano 24 września 2014 roku, zaś decyzję ustalającą wysokość emerytury z FUS oraz wysokość okresowej emerytury kapitałowej dopiero 13 marca 2015 roku.

Treść wszystkich trzech decyzji była niezadowalająca dla J.F. Po ich przeanalizowaniu okazało się, że łączna wysokość świadczenia emerytalnego (okresowa emerytura kapitałowa, emerytura z FUS wraz z kapitałem początkowym) wypłacanego miesięcznie brutto wyniesie $1287 \mathrm{zł}$ (1054 zł netto). Ponadto wykryto, że organ źle obliczył tzw. okresy składkowe i nieskładkowe, służące obliczaniu kapitału początkowego (art. 174 u.e.r.). Zauważono, że nie wszystkie okresy pracy i opłacania składek zostały przez ZUS w obliczeniach uwzględnione. Wysokość okresowej emerytury kapitałowej również budziła zastrzeżenia. Dlatego też zdecydowano o odwołaniu się od tych decyzji. Niestety każda $\mathrm{z}$ tych spraw toczyła się oddzielnym trybem w osobnym postępowaniu admi-

${ }^{7}$ Z. Turowska, Kapitat poczatkowy na przyszła emeryture - nowe uregulowania, „Prawo Pracy” 2006, nr 12, s. 23. 
nistracyjnym. Zarówno organ, jak też i wnioskodawca nie zauważyli, że trzy sprawy należałoby połączyć do wspólnego procedowania w myśl art. 62 k.p.a. (wszystkie przesłanki zostały spełnione) ${ }^{8}$.

Instytucja odwołania się od decyzji ZUS (organu rentownego) jest bardzo osobliwa. Jak już wspomniano postępowanie toczy się na zasadach administracyjnych z pewnymi odrębnościami. W myśl art. 181 k.p.a. organy odwoławcze od decyzji organów emerytalnych określają przepisy odrębne. W tym zaś przypadku - ustawa o systemie ubezpieczeń społecznych ${ }^{9}$. Czytamy tam w art. 83, ust. 2, pkt. 4, że od decyzji ZUS w sprawie przyznawanych świadczeń emerytalnych przysługuje ubezpieczonemu odwołanie do sądu. To zaś wnosi się i proceduje już na zasadach k.p.c. ${ }^{10}$

W związku z tym J.F. wniosła za pośrednictwem oddziału ZUS do sądu okręgowego w A. odwołania od wszystkich trzech osobnych decyzji organu rentowego (art. $477^{8}-477^{9}$ k.p.c.). Równocześnie wniesiono o połączenie trzech spraw do wspólnego rozpoznania (art. 219 k.p.c). W odwołaniach podniesiono, że organ rentowo-emerytalny źle przeprowadził postępowanie dowodowe skutkiem czego było nieuznanie części okresów ubezpieczenia. Ponadto podkreślono, że w decyzjach wskazano źle ewidencjonowane po roku 1999 wielkości składek na ubezpieczenie emerytalne. Skutkiem tych błędów świadczenie emerytalne zostało źle obliczone i rażąco zaniżone. Dodatkowo odwołująca się wniosła do sądu o przeprowadzenie dowodów z dokumentów złożonych do ZUS, dodatkowych dokumentów będących w posiadaniu J.F. oraz zeznań świadków.

Sąd Okręgowy w A. otrzymał od organu rentowego akta wraz z odwołaniem i wyznaczył pierwsze posiedzenie cztery miesiące później (lipiec 2015) w celu przeprowadzenia tzw. czynności wyjaśniających (art. 468 k.p.c.). Przed pierwszym posiedzeniem doszło jednak do zmiany niektórych przepisów emerytalnych. $Z$ dniem 1 maja 2015 roku wchodzi w życie ustawa o zmianie ustawy o emeryturach i rentach z Funduszu Ubezpieczeń Społecznych ${ }^{11}$. Na jej mocy w u.e.r. zostaje dodany art. 185a, w którym poleca się, w ramach procedury ustalania wysokości kapitału początkowego, uznawać za okresy nieskładkowe okres pobierania nauki w szkole wyższej. W związku z tym zdarzeniem J.F. składa do oddziału ZUS wniosek o przeliczenie świadczenia emerytalnego, żą-

\footnotetext{
${ }^{8}$ R. Hauser, Wszczęcie postępowania administracyjnego, „Ruch Prawniczy, Ekonomiczny i Socjologiczny" 1998; wyrok Naczelnego Sądu Administracyjnego w Warszawie z dnia 3 lutego 1999 r., I SA 630/98.

${ }^{9}$ Ustawa z dnia 13 października 1998 r. o systemie ubezpieczeń społecznych, Dz.U. z 2016 r. poz. 963.

${ }^{10}$ Por. A. Doliwa, D. R. Kijowski, P. J. Suwaj, Kryzys prawa administracyjnego?, Warszawa 2012, t. 3, s. 297-308.

${ }^{11}$ Ustawa z dnia 5 marca 2015 r. o zmianie ustawy o emeryturach i rentach z Funduszu Ubezpieczeń Społecznych, Dz.U. z 2015 r., poz. 552.
} 
dając zastosowania nowej regulacji. Organ rentowy zgadza się z wnioskiem i zwiększa wysokość kapitału początkowego. J.F. nie zgadza się z decyzją organu i wnosi od niej odwołanie do sądu okręgowego w A. Równocześnie wnosi o ponowne przeliczenie okresów składkowych i nieskładkowych w związku z nową regulacją ustawową. Wnosi też o połączenie tej czwartej sprawy do wspólnego rozpoznania ze sprawami wcześniejszymi.

\subsection{Postępowanie sądowe}

Posiedzenie w celu przeprowadzenia czynności wyjaśniających odbywa się w lipcu 2015 roku. Podczas niego ZUS oświadcza, że nie widział możliwości zmiany decyzji (art. $477^{9} \S 2 \mathrm{w}$ związku z art. $477^{13}$ k.p.c.). Sąd zgadza się na połączenie wszystkich czterech odwołań do wspólnego rozpoznania oraz zgadza się na realizację wniosków dowodowych. Informuje również, że uzyskał akta pracownicze J.F. z miejsc pracy. Powołuje biegłego sądowego w celu dokonania odpowiednich wyliczeń.

W toku postępowania sądowego odbyło się pięć rozpraw. W trakcie ich trwania sąd przeanalizował przesłane przez archiwa akta pracownicze, a także dokumenty złożone do akt organu emerytalnego (art. 472 k.p.c.). Materiał dowodowy został uzupełniony przez nowe zaświadczenia wydane przez byłe zakłady pracy. W toku postępowania sąd przesłuchał również czterech świadków pracy J.F. w organizacji społecznej na okoliczność pozostawania w zatrudnieniu i wysokości wynagrodzenia. Wyjaśnienia złożyła również odwołująca się. Uzyskano także opinie biegłego sądowego odnośnie wysokości wynagrodzenia uzyskiwanego w zakładzie przemysłowym.

15 stycznia 2016 roku sąd wydał wyrok. W myśl art. $477^{14} \S 2$ k.p.c. sąd zmienia ad meritum w całości lub części decyzje organu rentowego. Zgodnie z tym orzeczeniem sąd postanowił zmienić częściowo decyzję organu rentowego w zakresie obliczenia wysokości kapitału początkowego, korygując wysokość podstawy wymiaru kapitału początkowego. Dodatkowo sąd nakazuje ZUS wydanie nowych decyzji oraz uwzględnienie przy obliczaniu kapitału początkowego okresów pobierania nauki w szkole wyższej. Sąd oddala pozostałe wnioski J.F. m.in. w zakresie włączenia do okresów składkowych i nieskładkowych części okresów pracy przed rokiem 1999 oraz wniosek związany z rażącym zaniżeniem wysokości emerytury z FUS i okresowej emerytury kapitałowej.

W uzasadnieniu sąd wskazuje, że zeznania czterech świadków dotyczące zatrudnienia odwołującej się w organizacji społecznej były nieprzekonujące. Sąd nie dał wiary większości dokumentów wydanych w okresie zatrudnienia. Ponadto sąd uznał, że wysokość świadczenia emerytalnego jest adekwatna. Równocześnie uznał za wiarygodne zaświadczenia o wynagrodzeniu wydane przez byłe zakłady pracy już $\mathrm{w}$ toku prowadzonego postępowania przed or- 
ganem rentowym ${ }^{12}$. Sąd uznał również, że niektóre składniki wynagrodzenia uzyskiwanego przed 1989 rokiem nie podlegały składkowaniu ${ }^{13}$.

Z orzeczeniem nie zgodziła się odwołująca i wniosła apelację do sądu II instancji (Sąd Apelacyjny w K.). Zażądano uchylenia wyroku sądu okręgowego w tym ustalenia łącznego świadczenia emerytalnego w wysokości płacy minimalnej ${ }^{14}$. Podniesiono, że sąd okręgowy bardzo pobieżnie, niedokładnie i nieobiektywnie ocenił dowody. Szczególnie zwrócono uwagę na nie przyznanie wiary zeznaniom świadków. Ponadto zakwestionowano ocenę dowodów wydanych przed rokiem 1989. Zauważono, że powołany biegły sądowy przeprowadził swoją ekspertyzę jedynie w stosunku do części okresów zatrudnienia. Wskazano również, że sąd I instancji nie uwzględnił zatrudnienia J.F. w niektórych zakładach pracy ${ }^{15}$.

Dodatkowo wniosek apelacyjny oparto na bardziej ogólnych założeniach związanych z rażąco niską wysokością świadczenia emerytalnego. Zaakcentowano, że łączna wysokość emerytury nie pozwala na zaspokojenie podstawowych potrzeb życiowych, mieszkaniowych, zdrowotnych oraz narusza zasadę równości społecznej. Zarzucono, że ustalając wysokość świadczenia nie uwzględniono norm zawartych $\mathrm{w}$ art. 32, art. 67, art. 68 i art. 75 Konstytucji ${ }^{16}$. Dodatkowo podniesiono, że sąd nie uwzględnił norm zawartych w art. 12-14 oraz art. 16 Europejskiej Karty Społecznej ${ }^{17}$; art. 25-30 w związku z art. 65-68 Konwencji nr 102 MOP dotyczącej minimalnych norm zabezpieczenia społecznego ${ }^{18}$; art. $14 \mathrm{w}$ związku z art. $17 \mathrm{EKPC}^{19}$; art. 20, art. 21, art. 25, art. 34, art. 35, art. 41 Karty Praw Podstawowych UE ${ }^{20}$.

\footnotetext{
${ }^{12}$ R. Sadlik, Obowiązek wydania zaświadczenia Rp-7, „Służba Pracownicza” 12/2010, s. 23-24.

${ }^{13} \mathrm{~W}$ sprzeczności z rozporządzeniem Rady Ministrów z dnia 1 kwietnia 1985 r. w sprawie szczegółowych zasad ustalania podstawy wymiaru emerytur i rent, Dz.U. z 1989 r. Nr 11, poz. 63 ze zm.

${ }^{14}$ Ustawa z dnia 10 października 2002 r. o minimalnym wynagrodzeniu za pracę, Dz.U. z 2015 r., poz. $2008 \mathrm{ze}$ zm.

${ }^{15}$ Por. P. Walorska, Staż pracy, Warszawa 2014; T. Flemming-Kulesza, Problem kwestionowania przez zakład ubezpieczeń społecznych ważności umów o pracę, „Palestra” 2005, nr 9-10, s. 183.

${ }^{16}$ Konstytucja Rzeczypospolitej Polskiej z dnia 2 kwietnia 1997 r., Dz.U. z 1997 r. Nr 78, poz. 483 ze zm.

${ }^{17}$ Europejska Karta Społeczna sporządzona w Turynie dnia 18 października 1961 r., Dz.U. z 1999 r. Nr 8, poz. 67.

${ }^{18}$ Konwencja nr 102 Międzynarodowej Organizacji Pracy dotycząca minimalnych norm zabezpieczenia społecznego, przyjęta w Genewie dnia 28 czerwca 1952 r., Dz.U z 2005 r. Nr 93, poz. 775 .

${ }^{19}$ Konwencja o ochronie praw człowieka i podstawowych wolności sporządzona w Rzymie dnia 4 listopada 1950 r., zmieniona następnie Protokołami nr 3, 5 i 8 oraz uzupełniona Protokołem nr 2, Dz.U. z 1993 r. Nr 61, poz. 284.

${ }^{20}$ Karta praw podstawowych Unii Europejskiej, Dz.U.UE.C. z 2007 r. Nr 303, s. 1.
} 


\subsection{Problemy}

Opisywana sprawa służy jedynie za kanwę dla uwidocznienia i wytłumaczenia niektórych problemów powstających w toku analogicznych postępowań. Nie pokazuje ona wszystkich zawiłości i aspektów tego typu sytuacji. W żaden również sposób również nie uzurpuje sobie prawa do bycia reprezentatywną dla wszystkich podobnych sytuacji. Jest to jedynie przykład mający uświadomić czytelników, jak wiele problemów proceduralnych powstaje $\mathrm{w}$ toku procesu uzyskiwania emerytury.

\subsection{Odwołanie od decyzji}

W całym opisanym studium przypadku dominuje kwestia procedury. Przyglądając się tej sytuacji daję się zauważyć, że postępowanie w sprawie przyznawania świadczeń jest bardzo nieczytelne, trudne, podatne na wiele błędów. Natychmiast również odnotowuje się niecodzienne połączenie procedury administracyjnej i cywilnej. Warto bliżej przyjrzeć się tej sytuacji, gdyż jest ona coraz częściej spotykana w wielu nowych typach postępowań. Szczególnie, że dostrzega się pewną niespójność w kwestii odwołań od decyzji.

Organ rentowy prowadzi swoje postępowanie na podstawie k.p.a. Jest to typowy sposób prowadzenia postępowania we wszystkich sprawach o świadczenia emerytalno-rentowe ${ }^{21}$. Zgodnie z prawem administracyjnym (art. 12 k.p.a. w związku z art. 127 k.p.a.) strona ma prawo odwołania się od decyzji administracyjnej do organu II instancji. W tym wypadku ustawodawca postanowił o zastosowaniu trybu specjalnego w sprawach ubezpieczeniowych - odwołanie do sądu powszechnego (art. 83 ustawy systemowej). Tryb ten jest realizacją idei postępowania dwuinstancyjnego wskazanego w art. 176 Konstytucji. Dodatkowo jest o tyle bardziej słuszny od składania skarg do sądu administracyjnego, że w toku przewodu sąd bada zgodność decyzji ZUS głównie w zakresie naruszenia prawa materialnego - ad meritum (art. $477^{14} \S 2$ k.p.c.). W przypadku ewentualnego zastosowania trybu skargi administracyjnej sąd badałby głównie decyzję ZUS pod względem proceduralnym. To zaś ograniczyłoby środki ochrony wnioskodawcy - ubezpieczonego ${ }^{22}$.

W tym jednak miejscu rodzi się zasadniczy problem. Zgodnie z art. 127 k.p.a. w trybie administracyjnym strona ma prawo do odwołania się do jednej instancji (organ II stopnia). Czyni to odwołując się do sądu powszechnego,

\footnotetext{
${ }^{21}$ Por. art. 95 ustawy z dnia 14 grudnia 1982 r. o zaopatrzeniu emerytalnym pracowników i ich rodzin, Dz.U. z 1982 r. Nr 40, poz. 267 ze zm.

${ }^{22}$ K. Antonów i in., Prawo pracy i ubezpieczeń społecznych, Warszawa 2015, s. 742, 750-754; wyrok Sądu Najwyższego z dnia 9 lutego 2010 r. I UK 151/09; wyrok Sądu Najwyższego z dnia 21 stycznia 2013 r. II UK 164/12; wyrok Sądu Najwyższego z dnia 25 listopada 2016 r. I UK $369 / 15$.
} 
który proceduje sprawę w trybie k.p.c., lecz jest równocześnie organem odwoławczym w myśl norm administracyjnych. Jednak art. 176 Konstytucji zawiera normę wskazującą, że postępowanie sądowe również musi być dwuinstancyjne. W jaki więc sposób pogodzić sytuację, w której od wyroku sądu przysługuje apelacja do sądu II instancji (sądu apelacyjnego), kiedy to owy sąd I instancji jest zarówno organem sądowym pierwszoinstancyjnym, jak też drugoinstancyjnym organem odwoławczym od decyzji administracyjnej. Wygląda na to, że brakuje w całej procedurze jednej instancji (obecnie są jedynie trzy).

Wydaję się, że tego problemu dotychczas nie zauważono zarówno w jurydykaturze jak i doktrynie ${ }^{23}$. Jednak taka sytuacja wymaga dokładnego wyjaśnienia, gdyż może budzić wątpliwości natury konstytucyjnej i prawnomiędzynarodowej. $Z$ pewnością należałoby problem wyjaśnić, raczej przedstawić pod rozwagę Trybunału Konstytucyjnego, bądź zmienić ustawę w zakresie odwoływania się od poszczególnych decyzji organu i sądu.

\subsection{Postępowanie dowodowe}

Niemałym problemem całego postępowania jest kwestia postępowania dowodowego, w tym oceny dowodów. Opierając się na przepisach procedury związanej z udzielaniem świadczeń, organ prowadzący postępowanie żąda od wnioskodawcy przedstawienia dowodów okresów zatrudnienia i wysokość odprowadzonych składek na zasadach ustalonych w art. 117 u.e.r. oraz §17$\S 30$ rozporządzenia dotyczącego postępowania w sprawach emerytalno-rentowych $^{24}$. W akcie wykonawczym i samej ustawie czytamy, że należy stosować jego zapisy chyba, że ustawy stanowią inaczej. Widzimy wyraźnie, że organ jest ograniczony dowodowo zakresem ustawy i rozporządzenia. Organ odwoławczy (sąd) już tego ograniczenia mieć nie będzie (art. 473 k.p.c.) ${ }^{25}$. Powstaje jednak pewien problem, który dotychczas nie znalazł swojej interpretacji. Ustawa o u.e.r. wyraźnie wskazuje, że jej postanowienia w zakresie uznawalności dowodów, należy stosować tylko wtedy, gdy inne akty inaczej nie stanowią. Powstaje zaś konflikt tej normy z ogólnymi zasadami k.p.a. dotyczącymi dowodów. W myśl art. 75 k.p.a. jako dowód należy dopuścić wszystko co może przyczynić się do wyjaśnienia sprawy. Wynikałoby z tego, że w postępowaniu w zakresie ubezpieczeń społecznych nie powinny występować żadne ograniczenia w zakresie dopuszczania dowodów.

\footnotetext{
${ }^{23}$ Por. M. Klimas, Postępowanie sadowe w sprawach z zakresu ubezpieczeń społecznych, Warszawa 2013, s. 225, 243.

${ }^{24}$ Rozporządzenie Ministra Pracy i Polityki Społecznej z dnia 11 października 2011 r. w sprawie postępowania o świadczenia emerytalno-rentowe, Dz.U. z 2011 r. Nr 237, poz. 1412.

${ }^{25}$ K. Antonów i in., op. cit., s. 736-738; postanowienie Sądu Najwyższego z dnia 9 stycznia 2012 r. I UK 278/11; wyrok Sądu Najwyższego z dnia 2 lutego 1996 r. II URN 3/95.
} 
Należy również przyjrzeć się art. 220 k.p.a. Ustawodawca wskazuje tam jednoznacznie, że organ nie może żądać składania oświadczeń i zaświadczeń w określonych sytuacjach. ZUS jednak w niniejszej sprawie i sprawach analogicznych wymaga od wnioskodawców składania niektórych dowodów pozostawania w zatrudnieniu. Wydaję się to być sprzeczne $\mathrm{z}$ wymienionymi wyżej normami. Powstaje pytanie, czy prawodawca buduje tutaj normy kolizyjne w zakresie postępowania dowodowego pomiędzy ogólnym postępowaniem administracyjnym a szczególnym w zakresie ubezpieczeń społecznych. Wnioskodawcy, podobnie jak organowi, trudno jest zdecydować, do których norm ma się stosować. Niestety dotychczas ta sprawa nie został również wyjaśniona, co powoduje daleko idące problemy ${ }^{26}$.

Na podstawie tej sytuacji powinno się raczej wnioskować, że organ powinien dopuszczać wszystkie możliwe dowody mogące mieć wpływ na wyjaśnienie sprawy. Ponadto winien z własnej inicjatywy pozyskiwać inne zaświadczenia i oświadczenia bez udziału strony. Wynika to jednoznacznie nie tylko $\mathrm{z}$ cytowanych regulacji, lecz również z realizacji nadrzędnej zasady wyrażonej w art. 7 k.p.a.: ,[...] organy administracji publicznej stoją na straży praworządności i podejmują wszelkie kroki niezbędne do dokładnego wyjaśnienia stanu faktycznego oraz do załatwienia sprawy, mając na względzie interes społeczny i słuszny interes obywateli", oraz normy zawartej w art. 12 k.p.a. - zasada szybkości i prostoty postępowania. W przypadku zaś nieuwzględnienia innych dowodów i braku proaktywnej działalności ZUS w kwestii dowodów, pozostaje jedynie wniesienie odwołania do sądu na decyzję ZUS, bądź jego bezczynność trwającą ponad dwa miesiące.

Rodzą się kolejne wątpliwości dotyczące dowodów. Polegają one na trudności w ocenie dowodów zarówno na etapie postępowania administracyjnego, jak też i sądowego. O ile w tym pierwszym, organ rentowy zazwyczaj opiera się jedynie na pisemnych dowodach, o tyle sąd ma już pełną swobodę w ocenie materiału. Sprawy o udzielenie emerytur są o tyle specyficzne, że postępowanie dotyczy faktów, które miały miejsce nierzadko kilkadziesiąt (nawet 50) lat wcześniej. Ocena więc dowodów z zeznań świadków, czy dokumentów wydanych w innych realiach politycznych (w państwie socjalistycznym) a nawet w innym kraju (np. III Rzeszy, czy tzw. Kresach Wschodnich) jest niezwykle trudna. Wynika to również z tego, że wiele dokumentów zaginęła, świadkowie zmarli, zakład ubezpieczeniowy indywidualnie nie ewidencjonował odprowadzanych składek do roku 1992.

W takim stanie faktycznym niezwykle ważnym jest zebranie i ocena możliwie całego materiału dowodowego. Niestety często bywa to niemożliwe ze strony organu rentowego i sądu. Dlatego też instytucje tak silnie żądają od wnioskodawców przedstawiania poświadczeń pracy nawet wówczas, gdy na podstawie

${ }^{26}$ Por. M. Klimas, op. cit., s. 102. 
cytowanych regulacji, winny zrobić to we własnym zakresie. Takie zaniechanie organu lub sądu prowadzi do powstawania braków w pełnej dokumentacji, co ogranicza możliwości poprawnej analizy materiału. Na dodatek nie małą rolę odgrywają trudności $\mathrm{w}$ analizie skomplikowanych zapisów faktycznych i rachunkowych oraz realiów społecznych, historycznych i prawnych, w których powstały przedstawione dowody. $\mathrm{W}$ ten sposób organ, bądź sąd muszą podejmować decyzje na podstawie szczątkowych informacji. Wydaję się, że zarówno organ, jak też sądy winny gremialnie korzystać z pomocy specjalistów i biegłych zarówno w kwestiach rachunkowych, jak też historycznych i dyplomatycznych. Jedynie posiłkując się opiniami specjalistów można podejmować słuszne decyzje w oparciu o dowody wytworzone wiele lat wcześniej. Niestety obecnie oba typy instytucji rzadko godzą się na angażowania do postępowania fachowców. Zapewne generuje to nazbyt wiele trudów i kosztów. Dlatego też jedynie sądy rzadko zgadzają się na powoływanie biegłych z zakresu rachunkowości. Funkcjonuje to jednak z nazbyt ograniczonym zakresie.

Pewną formą zastępczą dla opinii specjalistów jest żądanie przedstawienia nowych zaświadczeń o zatrudnieniu i wynagrodzeniu od byłych zakładów pracy. ZUS zazwyczaj obarcza takim obowiązkiem bezpośrednio wnioskodawcę (niesłusznie), sąd raczej z własnej inicjatywy pozyskuje tego typu dokumenty. Jeżeli nadal istnieją byłe zakłady pracy przyszłych emerytów, to wówczas przedstawiają takie zaświadczenia. Jak pokazuje praktyka, dokumenty te są dla organu oraz sądów znacznie bardziej wiarygodne niż poświadczenia pracy wydane w toku świadczenia pracy przez wnioskodawcę. Niestety bardzo często są one niekompletne, niezrozumiałe, sprzeczne z dokumentami źródłowymi wydanymi wiele lat wcześniej (np. świadectwa pracy). Wprowadza to bardzo poważny kłopot w ocenie dowodów. Często organ, bądź sąd dają wiarę nowym dokumentom, pomijając te dawne. Praktyka taka, chociaż niesłuszna, winna być poddawana głębokiej analizie przy udziale ekspertów-biegłych. Dopiero wówczas można by stwierdzić, które dowody są bardziej wiarygodne. W innym przypadku sytuacja ta prowadzi do jeszcze gorszej oceny dowodów przez ZUS, bądź sąd.

\subsection{Przewlekłość postępowania}

Często daje się zauważyć długotrwałość postępowania w sprawach o przyznanie emerytur. Jest to związane zarówno z normą zawartą $\mathrm{w}$ art. 118 ust. 1 u.e.r. (wydanie decyzji w terminie 30 dni od momentu wyjaśnienia ostatniej okoliczności), jak również koniecznością ponownej oceny dowodów przez sąd, wniesienie ewentualnej apelacji oraz procedowania wszystkich spraw osobno. Takie działanie jest niezwykle przewlekłe i sprzeczne z ogólnymi zasadami zaufania do organów administracji publicznej i sądów a także prowadzenia spraw bez zbędnej zwłoki. Niestety dopuszcza się prowadzenie takiego postępowania 
przez dłuższy okres czasu. Wynika to z możliwości wzywania wnioskodawcy do wielokrotnego uzupełnienie materiału dowodowego o poświadczenia pracy. Co prawda na takie działanie przysługuje skarga na przewlekłość postępowania do $\mathrm{WSA}^{27}$, to jednak jeszcze bardziej wydłuża procedurę. Nie ułatwia jej wcale osobne procedowanie kilku wniosków o udzielenie emerytury z FUS, emerytury kapitałowej oraz obliczenie kapitału początkowego. W każdym przypadku organ winien sprawy takie łączyć do wspólnego rozpoznania na mocy wspomnianego już art. 62 k.p.a. W związku z tym winien wydawać jedną decyzję w kilku powiązanych ze sobą sprawach (jak w opisanej sytuacji), od której przysługiwałby jeden środek odwoławczy. Inne postępowanie będzie pogłębiato ten problem.

\subsection{Wysokość świadczenia}

Niestety zauważane problemy powodują, że świadczenia na starość są nieprawidłowo obliczane (najczęściej zaniżane). Często powstaje sytuacja, w której emeryci otrzymują świadczenie emerytalne netto poniżej minimum socjalnego ${ }^{28}$, lecz powyżej granicy kryterium dochodowego dla otrzymania świadczeń pomocy społecznej ${ }^{29}$. Dlatego też ich zubożenie jest podwójne. Nie mogą korzystać z pomocy społecznej, zaś ich emerytura nie wystarcza na pokrycie podstawowych kosztów życia. Sytuacja taka może budzić pewne wątpliwości natury konstytucyjnej i prawno-międzynarodowej, które zostały tutaj już wspomniane.

Niestety dalsze prowadzenie w ten sposób spraw o ustalenie wysokości świadczeń emerytalnych będzie prowadziło do ubożenia społeczeństwa. Dotyka to szczególnie te osoby, które gros swego zawodowego życia spędziły przed rokiem 1999, czyli przed momentem wejścia w życie nowej ustawy emerytalnej. Właśnie te osoby nie mogły samodzielnie odkładać na emeryturę i musiały zawierzyć ZUS w zakresie ustalania ich kapitału początkowego (art. 173 u.e.r. $)^{30}$. Należałoby się zastanowić nad daleko idącymi zmianami w tym systemie. Przytaczany przykład postępowania można uznać właśnie za tego typu problem.

\footnotetext{
${ }^{27}$ E. Dziubińska-Lechnio, J. Kuźniar, Ubezpieczenia społeczne 2016, Warszawa 2016, s. 1151; wyrok Naczelnego Sądu Administracyjnego w Warszawie z dnia 16 grudnia 2015 r. I OSK $1222 / 15$.

${ }^{28}$ Struktura wysokości emerytur $i$ rent, http://www.zus.pl/baza-wiedzy/statystyka/opracowaniatematyczne/struktura-wysokosci-emerytur-i-rent (dostęp: 25.02.2017); Wysokość minimum socjalnego, https://www.ipiss.com.pl/?zaklady=minimum-socjalne (dostęp: 24.02.2017).

${ }^{29}$ Por. art. 8 ustawy z dnia 12 marca 2004 r. o pomocy społecznej, Dz.U. z 2016 r. poz. 930 ze zm. ${ }^{30}$ S. Majkowski, Emerytury nieproporcjonalne do składek, „Rzeczpospolita - Prawo co dnia” 2004, nr 3, s. 17.
} 


\section{Podsumowanie}

Większość przyszłych emerytów, którzy chociaż częściowo pracowali (mieli okresy składkowe, bądź nieskładkowe) przed rokiem 1999 boryka się z podobnymi sytuacjami i problemami jak te opisane w pierwszej części. Są to kłopoty systemowe bardzo głęboko zakorzenione w polskim systemie prawnym, społecznym i politycznym. Niestety większość obywateli przyjmuje decyzje organów rentowych bez faktycznej refleksji. Z powodu własnej niewiedzy, strachu, czy stanu zdrowia, godzą się z nimi. Rzadko emeryci składają sądowe odwołania od decyzji ZUS. W sądzie prowadzącym opisywaną sprawę w roku 2016 rozpoznawano jedynie 355 odwołań od decyzji ZUS. To bardzo mało w porównaniu do ilości wydawanych decyzji emerytalnych i innych procesowych spraw cywilnych w polskich sądach (w sądzie okręgowym prowadzącym sprawę to 7 razy więcej) ${ }^{31}$. Obywatele boją się odwoływać od niekorzystnych dla nich decyzji. Boją się kosztów postępowania i jego przewlekłości. Nie wierzą również w to, że mogą nie zgodzić się z licznymi błędnymi i krzywdzącymi decyzjami Zakładu Ubezpieczeń Społecznych.

\subsection{Komisja}

Wydaję się, że istnieje pewne rozwiązanie, które mogłoby rozwiązać problemy i usprawnić cały proces. Można by zaproponować nowy system przyznawania rent i emerytur, który w dużej mierze wzoruje się na rozwiązaniach nordyckich.

Postępowanie o przyznawanie rent i emerytur należy w całości wyłączyć z kompetencji ZUS i sądów oraz połączyć z analogicznymi postępowania prowadzonymi przez KRUS, ministerstwa, czy Urząd ds. Kombatantów i Osób Represjonowanych. W konsekwencji zlikwidowane zostaną odpowiednie sądowe i instytucjonalne jednostki zajmujące się tym problemem. Powołanie komisji właściwej dla prowadzenia postępowań emerytalnych, wzorowanych na polskich samorządowych kolegiach odwoławczych, może rozwiązać problemy proceduralne i faktyczne. W skład komisji wejdą specjaliści, przedstawiciele społeczeństwa obywatelskiego a także sędziowie oraz pracownicy ZUS. Komisja powinna prowadzić postępowanie trybie administracyjnym, mieć dostęp do pełnego materiału dowodowego, powoływałaby ewentualnych dodatkowych biegłych. Byłaby zupełnie niezależna od ZUS i sądów. Nowopowstający organ musi się cechować wysokim poziomem profesjonalizmu. Wysokie kryteria kompetencyjne stawiane jej członkom mają gwarantować ich specjalistyczną

\footnotetext{
${ }^{31}$ Sprawozdanie MS-S1 w sprawach cywilnych Sądu Okręgowego w A. za rok 2016; Sprawozdanie MS-S11/12 w sprawach z zakresu pracy i ubezpieczeń społecznych Sądu Okręgowego w A. za rok 2016.
} 
wiedzę i doświadczenie. Od decyzji komisji powinno przysługiwać odwołanie do komisji krajowej, która również merytorycznie rozpatrywałaby sprawę. Dopiero po jej ostatecznej decyzji strona powinna mieć możliwość wniesienia skargi na błędy proceduralne do sądu administracyjnego. Rozwiązanie takie sprawia, że w procedurze będą uczestniczyć jedynie niezależni profesjonaliści o wysokich kwalifikacjach, rozszerza możliwości dowodowe i pogłębia ich analizę, odciąża sądy od zajmowania się szczegółowymi sprawami. W konsekwencji czyni ostateczną decyzję bardziej sprawiedliwą.

\subsection{Rozwiązanie nordyckie}

Komisje tego typu są podstawą funkcjonowania systemów pomocy społecznej i emerytalnych w całej Europie ${ }^{32}$. Znakomicie funkcjonują w krajach nordyckich. W sytuacji niezgody na decyzję organu w sprawie emerytury, składa się odwołanie do komisji, która w przeciągu trzech miesięcy podejmuje merytoryczną decyzję w trybie administracyjnym. Rozstrzygnięcia są wydawane przez specjalistów w oparciu o ekspertyzy i dowody pozyskane przez ten niezależny organ. Nie obciąża to sądów i nie generuje większych kosztów. Wnioskodawca nie uczestniczy w procesie, chociaż ma takie prawo, gdyż powołany z urzędu jego rzecznik zajmuje się zebraniem dowodów, ,pilnowaniem” komisji, czy wniesieniem odwołań. Równocześnie proces jest przejrzysty i szybki. Przyszły emeryt ma wgląd do sprawy przez Internet, bądź telefonicznie. Tymi drogami może składać ewentualne wnioski. Większość spraw kończy się w czasie krótszym niż miesiąc. Jedynie $10 \%$ spraw trafia do komisji odwoławczej w stolicy. Niemalże nie ma sytuacji, w których zostaje złożona skarga do sądu, pomimo istnienia takiej prawnej możliwości ${ }^{33}$.

Pomimo regularnych „reform” systemu emerytalnego niewiele się w nim zmienia. Należy podjąć zdecydowane reformy w procedurze przyznawania emerytur i rent tak, aby określone problemy uległy wyeliminowaniu. Z pewnością należałoby ujednolicić tryb wnioskowania, uzyskiwania i ewentualnego odwoływania się od decyzji w sprawie emerytur. Obecny system administracyjno-cywilny jest niezrozumiały, przewlekły, mało efektywny i podatny na błędy. Pochylić się trzeba również nad kwestią dowodową w całym postępowaniu. Raczej należałoby zdjąć obostrzenia w uznawaniu dowodów oraz konieczność przedstawiania tych dowodów przez wnioskodawcę. Bez wątpienia trzeba zadbać o pełną przejrzystość i szybkość procesu. Nie można również godzić się na

\footnotetext{
${ }^{32}$ Por. J. Knyżewska, Zabezpieczenie społeczne w Unii Europejskiej, cz. II. Emerytury i renty, „Służba Pracownicza” 2014, nr 2, s. 1-36.

${ }^{33}$ W Norwegii i Finlandii, Hvordan er det norske pensjonssystemet bygd opp? - www.nav.no, https://www.nav.no/no/Person/Pensjon/Alderspensjon/hvordan-er-det-norske-pensjonssystemet-bygdno-opp; Vakuutusoikeus (dostęp: 24.02.2017); http://www.vakuutusoikeus.fi/ (dostęp: 24.02.2017).
} 
prowadzenie kilku postępowań w stosunku do jednej sprawy i osoby. Nie zapominajmy również, że angażowanie do całego procesu aparatu sądowego prowadzi do nadmiernego obciążenia sądów, kosztów i przewlekłości postępowania. Warto także zaangażować więcej profesjonalistów w proces zbierania i oceny dowodów, tak, aby upływający czas i niekompetencja urzędnicza nie miały wpływu na ich wiarygodność. Osobną kwestią jest problem wysokości emerytur i ich opłacalności dla obywateli i państwa. Dodatkową potrzebą jest uzupełnienie luk w prawie i ewentualne go dostosowanie do norm konstytucyjnych i prawno-międzynarodowych a także usunięcie niektórych norm kolizyjnych powstających na styku procedury cywilnej i administracyjnej.

Opisywane problemy są wyborem kłopotów, jakie powstają w trakcie ubiegania się o emeryturę z ZUS. Oparto je jedynie na cytowanej sprawie, lecz są one dość powszechne. Niestety brak rozwiązań prowadzi do pogłębiania się chaosu, niesprawiedliwości i błędów. Nadszedł już czas, aby poważnie zająć się zmianami. Proponowane powołanie komisji jest jedynie jedną z możliwości. Niemniej wzorowanie reform na sprawnie funkcjonujących rozwiązaniach północnoeuropejskich może przynieść znaczącą poprawę. W innym wypadku polska procedura przyznawania emerytur może się prędko załamać ${ }^{34}$.

\section{Bibliografia}

\section{Literatura}

Antonów K., Baran W., Ćwiertniak M., Dörre-Nowak D., Walczak K., Prawo pracy i ubezpieczeń spotecznych, Warszawa 2015.

Doliwa A., Kijowski D. R., Suwaj P. J., Kryzys prawa administracyjnego? Warszawa 2012, t. 3.

Dziubińska-Lechnio E., Kuźniar J., Ubezpieczenia społeczne 2016, Warszawa 2016.

Flemming-Kulesza T., Problem kwestionowania przez zakład ubezpieczeń społecznych ważności umów o pracę, „Palestra” 2005, nr 9-10.

Hauser R., Wszczęcie postępowania administracyjnego, „Ruch Prawniczy, Ekonomiczny i Socjologiczny", 1998, nr 1.

Klimas M., Postępowanie sadowe w sprawach z zakresu ubezpieczeń społecznych, Warszawa 2013.

Knyżewska J., Zabezpieczenie społeczne w Unii Europejskiej, cz. II. Emerytury i renty, „Służba Pracownicza" 2014, nr 2.

Majkowski S., Emerytury nieproporcjonalne do składek, „Rzeczpospolita - Prawo co dnia” 2004, nr 3.

Sadlik R. Obowiąek wydania zaświadczenia Rp-7, „Służba Pracownicza” 2010, nr 12.

Sowiński T., Rozważania nad postępująca degradacja systemu emerytalnego w Polsce, „Gdańskie Studia Prawnicze" 2013, nr 2.

\footnotetext{
${ }^{34}$ Por. T. Sowiński, Rozważania nad postępujaca degradacja systemu emerytalnego $w$ Polsce, „Gdańskie Studia Prawnicze” 2013, nr 2, s. 125-136.
} 
Turowska Z., Kapitał początkowy na przyszła emeryture - nowe uregulowania, „Prawo Pracy” 2006, nr 12.

Walorska P., Staż pracy, Warszawa 2014.

Wiktorow A., Zabezpieczenie emerytalne w Polsce po transformacji ustrojowej. Możliwe kierunki dalszych zmian, „Przegląd Prawa i Administracji” 2014, nr 99.

\section{Akty prawne}

Karta praw podstawowych Unii Europejskiej, Dz.U. UE. C. z 2007 r. nr 303, str. 1.

Europejska Karta Społeczna sporządzona w Turynie dnia 18 października 1961 r., Dz.U. z 1999 r. Nr 8, poz. 67.

Konstytucja Rzeczypospolitej Polskiej z dnia 2 kwietnia 1997 r., Dz.U. z 1997 r. Nr 78, poz. 483 ze zm.

Konwencja nr 102 Międzynarodowej Organizacji Pracy dotycząca minimalnych norm zabezpieczenia społecznego, przyjęta w Genewie dnia 28 czerwca 1952 r., Dz.U. z 2005 r., Nr 93, poz. 775.

Konwencja o ochronie praw człowieka i podstawowych wolności sporządzona w Rzymie dnia 4 listopada 1950 r., zmieniona następnie Protokołami nr 3, 5 i 8 oraz uzupełniona Protokołem nr 2, Dz.U. z 1993 r. Nr 61, poz. 284.

Ustawa z dnia 14 czerwca 1960 r. Kodeks postępowania administracyjnego, Dz.U. z 2016 r. poz. 23.

Ustawa z dnia 17 listopada 1964 r. Kodeks postępowania cywilnego, Dz.U. z 2016 r. poz. 1822.

Ustawa z dnia 14 grudnia 1982 r. o zaopatrzeniu emerytalnym pracowników i ich rodzin, Dz.U. z 1982 r. Nr 40, poz. 267 ze zm.

Ustawa z dnia 13 października 1998 r. o systemie ubezpieczeń społecznych, Dz.U. z 2016 r., poz. 963.

Ustawa z dnia 17 grudnia 1998 r. o emeryturach i rentach z Funduszu Ubezpieczeń Społecznych, Dz.U. z 2016 r., poz. 887.

Ustawa z dnia 10 października 2002 r. o minimalnym wynagrodzeniu za pracę, Dz.U. z 2015 r., poz. 2008.

Ustawa z dnia 12 marca 2004 r. o pomocy społecznej, Dz.U. z 2016 r., poz. 930.

Ustawa z dnia 21 listopada 2008 r. o emeryturach kapitałowych, Dz.U. z 2014 r., poz. 1097.

Ustawa z dnia 5 marca 2015 r. o zmianie ustawy o emeryturach i rentach z Funduszu Ubezpieczeń Społecznych, Dz.U. z 2015 r., poz. 552.

Rozporządzenie Rady Ministrów z dnia 1 kwietnia 1985 r. w sprawie szczegółowych zasad ustalania podstawy wymiaru emerytur i rent, Dz.U. z 1989 r. Nr 11, poz. 63 ze zm.

Rozporządzenie Ministra Pracy i Polityki Społecznej z dnia 11 października 2011 r. w sprawie postępowania o świadczenia emerytalno-rentowe, Dz.U. z 2011 r. Nr 237, poz. 1412.

\section{Wyroki sądów}

Postanowienie Sądu Najwyższego z dnia 9 stycznia 2012 r., I UK 278/11, Lex nr 1215780.

Wyrok Sądu Najwyższego z dnia 2 lutego 1996 r., II URN 3/95, OSNP 1996/16/239.

Wyrok Naczelnego Sądu Administracyjnego w Warszawie z dnia 3 lutego 1999 r., I SA 630/98.

ONSA 2000/1/25.

Wyrok Sądu Najwyższego z dnia 9 lutego 2010 r., I UK 151/09, ONSA 2000/1/25.

Wyrok Sądu Najwyższego z dnia 21 stycznia 2013 r., II UK 164/12, OSNP 2013/21-22/261.

Wyrok Naczelnego Sądu Administracyjnego w Warszawie z dnia 16 grudnia 2015 r., I OSK 1222/15, Lex nr 1988002.

Wyrok Sądu Najwyższego z dnia 25 listopada 2016 r., I UK 369/15, Lex nr 2178665. 


\section{Sprawozdania}

Sprawozdanie MS-S1 w sprawach cywilnych Sądu Okręgowego w A. za rok 2016.

Sprawozdanie MS-S11/12 w sprawach z zakresu pracy i ubezpieczeń społecznych Sądu Okręgowego w A. za rok 2016.

\section{Źródła internetowe}

Hvordan er det norske pensjonssystemet bygd opp? https://www.nav.no/no/Person/Pensjon/Alderspensjon/hvordan-er-det-norske-pensjonssystemet-bygd-opp (dostęp: 24.02.2017).

Struktura wysokości emerytur i rent, http://www.zus.pl/baza-wiedzy/statystyka/opracowania-tematyczne/struktura-wysokosci-emerytur-i-rent (dostęp: 25.02.2017).

Vakuutusoikeus, http://www.vakuutusoikeus.fi/fi/ (dostęp: 24.02.2017).

Wysokość minimum socjalnego, https://www.ipiss.com.pl/?zaklady=minimum-socjalne. (dostęp: 24.02.2017). 